\title{
ANALISIS BIMBINGAN KELOMPOK TENTANG PELANGGARAN TATA TERTIB TERHADAP SISWA DI SEKOLAH MENENGAH ATAS PGRI 5 PALEMBANG
}

\author{
Juniar Saraswati ${ }^{1}$, Erfan Ramadhani ${ }^{2}$, Endang Surtiyoni ${ }^{3}$ \\ Universitas PGRI Palembang ${ }^{1}$ \\ Email: juniarsaraswati@gmail.com \\ Universitas PGRI Palembang ${ }^{2}$ \\ Email: erfankonselor@gmail.com \\ Universitas PGRI Palembang ${ }^{3}$ \\ Email: surtyoniendang@gmail.com
}

\begin{abstract}
ABSTRAK
Tujuan dari penelitian ini adalah untuk mengetahui adanya layanan bimbingan kelompok terhadap pelangaran tata tertib yang dilakukan oleh anak-anak kelas 11, untuk mengetahui adakah bentuk keberhasilan setelah di diberikan layanan bimbingan kelompok. Untuk mengatasi permasalahan ini maka guru bimbingan dan konseling memberikan layanan bimbingan kelompok dengan teknik diskusi kelompok untuk membantu siswa mengatasi permasalahan yang ada disekolahan. Metode yang dipakai yaitu deskriftif kualitatif dengan mengunakan teknik pengumpulan data melalui, observasi, wawancara, dokumentasi. Pelaksanaan layanan bimbingan kelompok dilakukan dengan 4 tahap yang meliputi pembentukan, peralihan, kegiatan dan pengakhiran, ke empat langkah tersebut sudah dilakukan guru BK Berdasarkan hasil penelitian dan analisis data, anak mengalami perubahan dari buruk ke baik. Dapat disimpulkan terdapat perbedaan yang signitifikan hasil perubahan perilaku siswa yang memperoleh bimbingan dari metode deskriptif kualitatif dengan siswa yang tidak memperoleh bimbingan di PGRI 5 Palembang.
\end{abstract}

Kata kunci : Analisis Layanan Bimbingan Kelompok, Pelanggaran Tata Tertib

\section{GROUP GUIDANCE ANALYSIS ON THE VIOLATION OF ORDER AGAINST STUDENTS AT SENIOR HIGH SCHOOL PGRI 5 PALEMBANG}

\begin{abstract}
The purpose of this study is to know that there is a group guidance service to the exclusion of order by the 11th graders, to know what kind of success there is after the group guidance services are given. To solve this problem, guidance and counseling teachers provide group guidance services with a group discussion technique to help students solve problems at school. The method used is qualitative descretive using data collection techniques through observation, interviews, documenting. Group guidance services are conducted with four stages that include formation, transition, activity and closure, with all four steps done by guidance teachers based on research and data analysis, children change from bad to good. Can be devising differences that result from changes in students' behavior that get guidance from qualitative descriptive methods with students who do not receive guidance at pgri 5 Palembang.
\end{abstract}

Keywords: Group Guidance Services Analysis, Violation Of Order 


\section{PENDAHULUAN}

Sekolah merupakan lembaga pendidikan formal yang terdiri dari berbagai komponen yaitu siswa, guru, kepala sekolah, staf tata usaha, dan lain sebagainya yang secara bersama-sama berada dalam satu lembaga, dan bersama-sama pula mengatur dan membina serta menyelanggarakan program-program yang ditentukan dan diatur oleh dinas pendidikan. Dalam upaya memudahkan pelaksanaan program yang sudah ada, maka sekolah membuat peraturan dan tata tertib sekolah.

Secara umum tata tertib sekolah dapat diartikan sebagai ikatan atau aturan yang harus dipatuhi setiap warga sekolah tempat berlagsungnya proses belajar mengajar. Perlaksanan tata tertib sekolah akan dapat berjalan dengan baik jika guru, aparat sekolah dan siswa telah saling mendukung terhadap tata tertib sekolah itu sendiri, kurangnya dukunganya dari siswa akan mengakibatkan kurang berartinya tata tertib sekolah yang diterapkan disekolah.Adanya peraturan tata tertib tersebut diharapkan dapat dijadikan rambu-rambu dalam berperilaku bagi semua individu dalam kegiatan proses pendidikan disekolah, misalnya bagaimana siswa berperilaku terhadap sesama teman, guru, kepala sekolah dan semua komponen yang ada didalamnya.

Salah satu unsur pokok dalam proses pendidikan yang perlu diperhatikan adalah bagaimana upaya sekolah menjadikan siswa berkepribadian yang sehat yang memiliki kemampuan untuk menyesuaikan diri secara tepat baik terhadap diri sendiri, keluarga, lingkungan sekolah dan masyarakat maupun terhadap tuhan yang maha esa. Salah satu ciri pribadi yang sehat adalah disiplin yaitu individu yang mampu menampilkan perilaku yang sesuai dengan batasan-batasan norma/aturan yang berlaku.

Relevensi dan kualitas pendidikan SMA merupakan pondasi yang amat menentukan keberhasilan pendidikan pada jenjang selanjutnya maka upaya menciptakan kedisiplinan ber-tata tertib disekolah sangat diharpkan. Banyak pelanggaran yang dilakukan oleh siswa kelas XIl-IPS antara lain seperti tidak tidak memaki atribut sekolah, keluar kelas ketika tidak ada guru, tidak masuk sekolah tanpa ijin / membolos, keluar kelas pada saat pergantian jam pelajaran, terlambat pada saat bel sudah berbunyi. Sering kita jumpati dilapangan banyak siswa yang kurang memperhatikan keberadaan bimbingan dan konseling disekolah karena 
pandangan siswa berurusan dengan guru BK hanya siswa yang melanggar taat tertib sekolah.

Sehubungan kenyataan dilapangan banyak perilau yang menyimpang dari ketentuan tata tertib sekolah maka layanan bimbingan kelompok perlu diberikan untuk memberikan bantuan kepada siswa agar dapat memahami tata tertib sekolah dan dapat berperilaku sesuai harapan sekolah.

Sebagaimana hasil studi pendahuluan yang dilakukan peneliti diSekolah Menegah Atas PGRI 5 Palembang selama PPL adapun data yang diperoleh dari peneliti melakukan pengamatan bahwa kelas XII IPS belum bisa menaati tata tertib yang ditentukan oleh sekolah seperti, membolos pada saat jam pelajaran, terlambat masuk sekolah, keluar kelas ketika tidak ada guru, keluar kelas ketika jam pergantian pelajaran, tidak memakai atribut yang ditentukan sekolah.

Dimana dari penjelasan diatas , maka penulis meneliti siswa kelas 12 dengan judul, yaitu “Analisis Bimbingan Kelompok Tentang Pelanggaran Tata Tertib Terhadap Siswa Di Sekolah Menengah Atas PGRI 5 Palembang.

\section{LANDASAN TEORI}

Tata tertib merupakan kosa kata yang terbentuk menggunakan imbuhan imbuhan baru. Pada dasarnya kata tertib berasal dari dua kata, yaitu kata "tata" yang artinya susunan, dan "tertib" yang artinya teratur, tidak acak-acakan. Jadi tata tertib berarti sebuah aturan yang dibuat secara tersusun dan teratur, serta saling berurutan dengan tujuan semua orang yang melaksanakan peraturan ini melakukannya sesuai dengan urutan-urutan yang telah dibuat. tata tertib dapat diartikan sebagai ikatan atau aturan yang harus dipatuhi setiap siswa tempat berlangsungnya proses belajar mengajar, adapun beberapa peraturan dalam sekolah yang sudah ditentukan oleh sekolah. Aturan-aturan ketertiban dalam keteraturan terhadap tata tertib sekolah, meliput Tujuan Tata Tertib Sekolah Secara umum, tata tertib sekolah mempunyai tujuan utama agar semua siswa sekolah mengetahui apa tugas, hak, dan kewajiban serta melaksanakan dengan baik sehingga kegiatan sekolah dapat berjalan dengan lancar. Prinsip tata tertib sekolah adalah diharuskan, dianjurkan, dan ada yang tidak boleh dilakukan dalam pergaulan di lingkungan sekolah. Menurut Kusmiati ,bahwa tujuan diadakannya tata tertib adalah: Berujuan peraturan keamanan adalah untuk mewujudkan rasa aman dan tentram serta bebas dari rasa takut baik lahir maupun 
batin yang dirasakan oleh seluruh warga, sebab jika antar individu tidak saling menggangu maka akan melahirkan perasaan tenang dalam diri Setiap individu dan siap untuk mengikuti kegiatan sehari-hari. Tata tertib sekolah harus ada sanksi atau hukuman bagi yang melanggarnya. Hukuman yang dijatuhkan sebagai jalan keluar terakhir harus dipertimbangkan perkembangan siswa.

Untuk menciptakan suasana yang aman dan tentram bagi seluruh siswa maka diadakan tujuan tata tertib sekolah diantaranya sebagai berikut :

1. Agar siswa mengetahui apa saja yang harus di taati yang sudah ditentukan oleh sekolah

2. Agar siswa mengetahui hal-hal yang diperbolehkan dan keativitas meningkat serta terhindar dari masalah-masalah yang dapat menyulitkan dirinya.

3. Agar siswa mengetahui dan melaksanakan dengan baik seluruh kegiatan yang telah diprogramkan oleh sekolah baik intrakurikuler maupun ekstrakurikuler kewajiban, keharusan dan larangan-larangan.

4. Menciptakan suasan yang bersih dan sehat bagi seluruh warga sekolah

5. Menciptakan suatu kondisi yang teratur yang mencerminkan keserasian, keselarasan, serta keseimbangan baik pada tata ruang, tata kerja, tata pergaulan, dan lain sebagainya di lingkungan sekolah.

6. Menciptakan lingkungan yang baik sehingga tercipta keindahan yang bisa dirasakan oleh seluruh warga sekolah

7. Untuk membina tata hubungan yang baik diantara para siswa, guru, dan warga sekolah lainnya yang mencerminkan sikap dan rasa gotong-royong, keterbukaan, saling membantu, saling menghormati, dan saling tenggang rasa.

Kepatuhan siswa terhadap tata tertib sekolah adalah yang bersumber dari dalam dirinya bukan karena paksaan atau tekanan dari pihak lain. Tingkat kesadaran seseorang terhadap tata tertib meliputi :

- Datang tepat waktu yang telah ditentukan oleh sekolah

- Memakai atribut sekolah yang lengkap

- Taat atas dasar adanya aturan dan hukum serta untuk ketertiban

Bimbingan kelompok adalah layanan bimbingan yang diberikan dalam suasana kelompok. Sementara Romlah (2001:3) mendefinisikan bahwa bimbingan kelompok merupakan salah satu teknik bimbingan yang berusaha membantu 
individu agar dapat mencapai perkembangannya secara optimal sesuai dengan kemampuan, bakat, minat, serta nilai-nilai yang dianutnya dan dilaksanakan dalam situasi kelompok. Bimbingan kelompok ditujukan untuk mencagah timbulnya masalah pada siswa dan mengembangkan potensi siswa.

Menurut juntika (2003) mendefinisikan bahwa bimbingan kelompok merupakan batuan terhadap individu yang dilaksanakan dalam situasi kelompok, bimbingan kelompok dapat berupa penyampaian informasi ataupun aktivitas kelompok membahas masalah-masalah pendidikan, pekerjaan, pribadi dan sosial.

Adapun tujuan bimbingan kelompok yang akan membantu siswa dalam mengikuti proses belajar mengajar secara optimal, selain itu bimbingan kelompok juga bertujuan untuk mengembangkan pribadi masing-masing anggota kelompok melalui berbagai susunan yang muncul dalam kegiatan kelompok, dan tujuan kelompok tersebut untuk mengetahui tingkatan kebrhasilan setelah diberikan layanan bimbingan kelompok terhadap siswa yang tidak mentaati tata tertib sekolah tersebut.

Mugiharso (2011:66), mengemukakan bahwa "fungsi utama bimbingan yang didukung oleh layanan bimbingan kelompok ialah fungsi pemahaman dan pengembangan." Jadi, berdasarkan dua pendapat ahli tersebut fungsi layanan bimbingan kelompok yaitu fungsi pemahaman dan fungsi pengembangan.

Penyelenggaraan layanan bimbingan kelompok dituntut untuk memenuhi sejumlah asas-asas bimbingan kelompok. Pemenuhan asas-asas bimbingan itu akan memperlancar pelaksanaan dan lebih menjamin keberhasilan kegiatan. Apabila asas-asas ini tidak dijalankan dengan baik, maka penyelenggaraan bimbingan kelompok akan berjalan tersendat-sendat atau bahkan terhenti sama sekali.

Kegiatan bimbingan kelompok berlangsung dalam beberapa tahap. Prayitno mengemukakan ada empat tahap kegiatan yang perlu dilalui dalam kegiatan bimbingan kelompok yaitu:

- Tahap permulaan, yaitu tahapan untuk membantuk kerumunan sejumlah individu menjadi satu kelompok yang siap mengembangkan dinamika kelompok dalam mencapai tujuan bersama,

1. Menerima secara terbuka dan mengucapkan terimakasih atas kesedian konseli untuk hadir dalam kegiatan ini.

2. Berdo'a 
3. Memperkenalkan diri secara terbuka, menjelaskan peranannya sebagai pemimpin kelompok.

4. Menjelaskan pengertian bimbingan kelompok

5. Menjelaskan tujuan umum yang ingin dicapai melalui bimbingan kelompok.

6. Menjealskan azaz-azaz bimbingan kelompok

7. Perkenalan dilanjutkan rangakaian nama.

- Tahap peralihan, yaitu tahapan untuk mengalihkan kegiatan awal kelompok ke kegiatan berikutnya yang lebih terarah pada pencapaian tujuan kelompok.

1. Menjelaskan kembali kegiatan kelompok

2. Tanya jawab tentang kesiapan anggota untuk kegiatan lebih lanjut

3. Mengenali suasana apabila anggota secara keseluruhan/sebagian belum siap untuk memasuki tahap berikutnya dan mengatasi suasana inti

4. Meningkatkan kemampuan keikutsertaan anggota.

- Tahap kegiatan, tahapan "kegiatan inti" untuk membahas topik-topik tertentu

1. Pemimpin kelompok mengemukakan topik bahasan yang telah dipersiapkan (topik tugas)

2. Menjelaskan pentingknya topik tersebut dibahas dalam kelompok

3. Tanya jawab tentang topik yang dikemukakan pemimpin kelompok

4. Pembahasan topik tersebut secara tuntas, gunakan rumus $5 \mathrm{~W}+1 \mathrm{H}$

5. Selingan

6. Menegaskan kembali komitmen per anggota kelompok (apa yang segera dilakukan berkenaan dengan topik yang telah dilakukan)

- Tahap pengakhiran, yaitu tahapan akhir kegiatan untuk melihat kembali apa yang sudah dilakukan dan dicapai oleh kelompok, serta merencanakan kegiatan selanjutnya.

1. Menjelaskan bahwa kegiatan bimbingan kelompok akan diakhiri

2. Anggota kelompok mengemukakan kesan dan menilai kemajuan yang dicapai masing-masing

3. Pembahasan kegiatan lanjutan

4. Pesen peserta tanggapan anggota kelompok

5. Ucapan terima kasih

6. Ber'doa 


\section{Perpisahan.}

Bentuk-bentuk bimbingan kelompok ada beberapa macam. Konselor harus dapat menilai dan melihat keadaan konselingnya dan dapat menggunakan layanan bimbingan kelompok dengan pas dan terarah, bberpa jenis metode bimbingan kelompok menurut surya (1975:75) yaitu :

1. Program home room

Program ini dilakukan diluar jam pelajaran dengan menciptakan kondisi sekolah atau kelas seperti dirumah sehingga tercipta kondisi yang bebas dan menyenagkan.

2. Karyawisata

Karyawisata dilaksanakan dengan mengujungi dan mengadakan peninjauan pada objek-objek yang menarik yang berkaitan dengan isu, masalah, atau topik kehidupan tertentu

3. Diskusi kelompok

Diskusi kelompok merupakan suatu cara dimana peserta didik memperoleh kesempatan untuk memecahkan masalah secara bersama-sama.

4. Kegiatan kelompok

Kegiatan kelompok dapat menjadi suatu teknik yang baik dalam bimbingan, karena kelompok dapat memeberika kesempatan pada individu untuk berpartisipasi secara baik.

5. Sosiodrama

Sosidrama dapat digunakan sebagi salah satu cara bimbingan kelompok. Sosiodrama merupakan suatu cara membantu memecahkan masalah peserta didik melalui drama.

\section{Psikodrama}

Hampir sama dengan sosiodrama. Psikodrama adalah upaya pemecahaan masalah melalui drama. Bedanya adalah masalah yang didramkan. Dalam sosiodrama masalah yang diangkat adalah maslah sosial, akan tetapi pada psikodrama yang didramakan adalah masalah psikis yang dialami individu. 


\section{METODE PENELITIAN}

Metode yang dilakukan dalam penelitian ini adalah penelitian kualitatif deskriftif. Dimana peneliti melakukan informasi atau data yang berkaitan dengan masalah yang diteliti kemudian peneliti menarik kesimpulan informasi dari data yang diteliti. Metode deskriftif dianggap sesuai dengan peneliti ini, karena peneliti ingin menganalisis layanan bimbingan kelompok tentang pelanggaran tata tertib terhadap siswa di SMA Pgri 5 Palembang.

Menurut sugiyono (2016:2) metode penelitian merupakan cara ilimiah untuk mendapatkan data dengan tujuan dan keguruan tertentu. Sedangkan menurut Moh. Nazir (2003:4) pengertian "Metode deskriptif adalah suatu metode dalam meneliti status kelompok manusia, suatu objek, suatu set kondisi, suatu sistem pemikiran, ataupun suatu kelas peristiwa pada masa sekarang”.

Dari definisi di atas dapat disimpulkan bahwa penelitian deskriptif kualitatif adalah suatu metode atau cara dalam meneliti status sekelompok manusia, suatu objek dengan membuat deskriptif, gambaran atau lukisan secara sistematis, faktual dan akurat mengenai fakta-fakta atau fenomena yang diselididki dengan apa adanya. Untuk menggambarkan secara utuh dan mendalam tentang realitas sosial dan berbagai fenomena yang terjadi dimasyarakat yang menjadi subjek penelitian, maka dalam penelitian ini penting menggunakan deskriptif kualitatif.

\section{HASIL PENELITIAN DAN PEMBAHASAN}

\section{HASIL PENELITIAN}

Dalam penelitian ini pengumpulan data dilakukan untuk memperoleh informasi yang dibutuhkan dalam rangka mencapai tujuan penelitian, kemudian peneliti menjelaskan teknik dan prosedur yang digunakan dalam pengumpulan data adapun diantaranya yang harus digunakan oleh peneliti pada saat akan melakukan penelitian yaitu sebagai berikut :

\section{Observasi}

Observasi atau pengamatan yang cermat dapat dianggapan sebagai salah satu penelitian ilmiah yang paling sesuai dengan bidang ilmu sosial tanpa harus memerlukan biaya yang banyak, sehingga penelitian dapat dilakukan. Menurut yusuf, (2011) menjelaskan bahwa observasi merupakan pengamatan yang diteliti 
dan sistematis tentang suatu objek, melalui observasi seseorang dapat mengetahui tingkah laku dari objek yang diamati.

Dari definisi diatas dapat disimpulkan bahwa observasi merupakan suatu kegiatan pengamatan dan pencatatan yang dilakukan secara sistematis dengan terlebih dahulu merencanakan secara matang obyek yang ingin diteliti. Dalam melakukan peneliti ini peneliti melakukan observasi awal dengan cara mengamati tempat lokasi penelitian, untuk menganalisis bimbingan kelompok mendorong siswa mentaati taat tertib sekolah di SMA PGRI 5 Palembang.

2. Wawancara

Wawancara merupakan salah satu teknik yang dapat digunakan untuk mengumpulkan data penelitian. Wawancara dapat didefinisiskan sebagai proses pertemuan dua orang untuk bertukar informasi dan ide melalui tanya jawab sehingga dapat dikonstruksi makna dalam suatu topik tertentu (Sugiono, 2009). Melalui wawancaea, peneliti akan mengetahui hal-hal yang lebih mendalam tentang partisispan dalam menginterprestasikan situasi dan fenomena yang terjadi tidakn mungkin bisa ditemukan melalui observasi. Penelitian kualitatif sering menggabungkan teknik observasi partisipatif dengan wawancara mendalam.

Berdasarkan pendapat diatas wawancara merupakan suatu cara pengumpulan data dengan menggunakan komunikasi secara langsung dengan mengemukakan pertanyaan-pertanyaan secara langsung dan dijawab secara langsung pula. Dalam peneliti ini peneliti menggunakan wawancara tidak berstruktur. Wawancara tidak berstruktur adalah wawancara yang bebas, peneliti tidak menggunakan pedoman wawancara yang telah tersesusun secara sistematis dan lengkap untuk mengumpulkan data-datanya

\section{Dokumentasi}

Dokumentasi merupakan teknik pengumpulan data dengan cara memperoleh informasi dari bermacam-macam sumber tertulis atau dokumentasi yang ada pada responden atau tempat, dimana responden bertempat tinggal atau melakukan kegiatan sehari-harinya (Sukardi, 2010). Dokumentasi bisa berbentuk tulisan, gambar, atau karya-karya monumental dari seseorang. Studi dokumentasi merupakan pelengkap dari pengunakan metode observasi dan wawancara dalam penelitian kualitatif untuk mendpatkan hasil penelitian yang lebih kredibel atau dapat dipercaya. Bentuk dokumentasi menurut haris (2010) dibedakan menjadi dua, 
yaitu: a) dokumen pribadi, seperti catatan haian, sirat pribadi. B) dokumentasi resmi berupa: surat keputusan, memo, surat intruksi, dan surat bukti kegiatan yang dikeluarkan oleh instansi.

\section{PEMBAHASAN}

Dalam pembahasan ini berdasarkan diperoleh dari lapangan dari hasil analisi obsevasi, wawancara dan dokumentasi dari guru bimbingan konseling peserta didik mengalami permasalahan terhadap pertauran tata tertib disekolah. Dalam penelitian ini peneliti mengambil sampel dari kelas XI IPS yang ada di SMA Pgri 5 Palembang. Dalam proses penelitian peneliti melakukan layanan bimbingan kelompok dimana ada penjelasan sesuai fakta yang diperoleh dilapangan bahwa faktor yang menyebabkan peserta didik melanggar tata tertib sekolah salah satunya karena faktor lingkungan. wawancara yang dilakukan peneliti kepada peserta didik bahwa sikap melanggar tata tertib karena faktor pengaruh dari teman, misalkan terlambat kesekolah karena malamnya menonton bola sampai larut malam mengakibtkan anak kesiangan dan akhirnya terlambat. Dan setelah hasil wawancara dengan guru BK ternyata yang diungkapkan sama halnya karena faktor lingkungan,

Setelah guru Bimbingan dan Konseling mengetahui permasalahan yang dialami oleh peserta didiknya guru Bimbingan dan Konseling mengambil tindakan dalam membantu peserta didiknya yaitu dengan memberikan layanan bimbingan kelompok secara efektif dengan waktu yang cukup memadai agar dapat mengatasi pelanggaran tata tertib sekolah di SMA Pgri 5 Palembang. Sebelum melaksanakan proses pemberian layanan bimbingan kelompok guru Bimbingan dan Konseling mendata peserta didiknya yang melakukan pelanggaran tata tertib sekolah setelah Guru Bimbingan dan Konseling mendapatkan peserta didik yang bermasalah tersebut dan bersepakat untuk melakukan bimbingan kelompok sesuai dengan waktu dan jam yang telah disepakati.

Setelah selesai melakukan pelaksanaan layanan bimbingan kelompok ternyata hasil yang didapat cukup baik walaupun belum maksimal, karena dilihat dari pengamatan yang ada bahwa peserta didiknya yang tahap demi tahap dapat merubah perilakunya yang negatif menjadi perilaku positif. Peserta didik yang tadinya sering melanggar tata tertib seperti datang terlambat, membolos, keluar 
masuk jam pelajaran dan sebagainya ternyata bisa merubah perilaku ke yang lebih baik, seperti tidak datang terlambat, tidak keluar masuk jam pelajaran, tidak membolos lagi

Melihat frekuensi kedisiplinan peserta didik yang mengalami penurunan selama kurang lebih 6 minggu terakhir dengan ditandai berkurangnya jumlah pelanggaran kedisiplinan tata tertib yang dilakukan peserta didik di sekolah.Halini menunjukan bahwa guru BK berperan dalam mengatasi dan membantu permasalahan peserta didik dengan menggunakan layanan bimbingan kelompok untuk meningkatkan kedisiplinan tata tertib peserta didik di sekolah, diharapkan pada tahun ajaran baru ditindak lanjuti secara optimal dan efektif dengan memperhatikan kekurangan dan kelebihan dalam proses pelaksanaan kegiatan layanan yang telah dilakukan, dengan memberikan layanan informasi dan orientasi pada saat penerimaan siswa baru agar kebiasaan buruk semasa SMP tidak dibawa dan terulang ketika memasuki jenjang SMA.

\section{KESIMPULAN}

Berdasarkan hasil penelitian dan pembahasan yang telah dilakukan , dapat diambil kesimpulan sebagai berikut :

1. Teknik layanan bimbingan kelompok yang diberikan peneliti dapat merubah siswa yang sering melanggar tata tertib sekolah. Dimana dapat dilihat dari data sata pelaksaan layanan bimbingan kelompok.

2. Teknik layanan bimbingan kelompok berjalan dengan lacar sesuai dengan apa yang di tentukan sekolah siswa-siswa dapat merubah kebiasan buruknya, sekarang siswa tersebut merubah sikapnya dengan tingkah laku yang rajin dan menurut apa yang harus ditenukan sekolah.

3. Faktor pendukung dalam Guru Bimbingan dan Konseling juga terbuka dan sering memantau dari jauh peserta didik yang sudah di beri layanan bimbingan kelompok. Jika masih ada siswa yang sering terlambat maka diberikan hukuman seperti menghapal pelajran hari itu. 


\section{DAFTAR PUSTAKA}

Anne Merial Fianti. 2015. Tata Tertib Menurut Dekdibud dian nemeri15 .blogspot.com/2 015/11/tata-tertib-sekolah-pengertian-tata.html (diakses pada tanggal 18 Maret 2019

Deni Siregar. M. Juni 2015. Kontribusi Pemberian Layanan Bimbingan Kelompok Untuk Meningkatkan Kedisiplinan Siswa. Mahasiswa Program Studi Bimbingan dan Konseling STKIP Hamzanwadi Selong. Indonesia

Dian Pratiwi, Muswardi Rosra dan Ratna Widia Astuti. 2014. Pengunaan Layanan Konseling Kelompok Dalam Mengurangi Pelanggaran Tata Tertib Siswa di Sekolah. Indonesia

Dimas Baruna. Gerysa. 2016. Pengaruh Bimbingan Kelompok Terhadap Peningkatan Kedisiplinan dan Tata Tertib Sekolah Pada Siswa. Indonesia

M. Ferdiansyah. April 2015. Dasar Penelitian Kualitatif. Bogor : Herya Media Cetakan Pertama.

Siagian. Melina. 2017. Pengaruh Layanan Bimbingan Kelompok Terhadap Kedisiplinan Siwa Madrasah Tsanawiyah Al-ikhlas Aek Botik Tapanuli Utara. Mahasiswa Program Studi Bimbingan dan Konseling Universitas Islam Negri Sumatera Utara Medan. Indonesia

Sugiyono. 2016. Metode Penelitiann Pendidikan Kuantitatif, Kualitatif dan R\&D. Bandung : Alfabeta.

Tim Penyusun. 2019. Pedoman Penulisan Skripsi. Palembang: FKIP Universitas PGRI Palembang. 